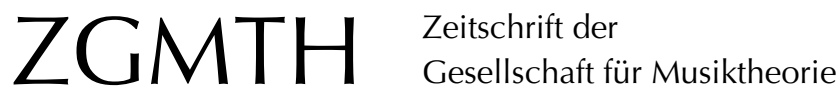

Neal, Jocelyn (2003/05): Popular Music Analysis in American Music Theory. ZGMTH 1-2/2/2-3, 173-180. https://doi.org/10.31751/524

(C) 2003/05 Jocelyn Neal

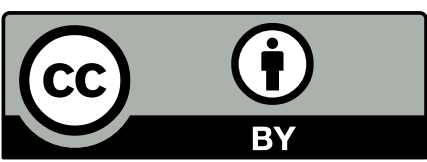

Dieser Text erscheint im Open Access und ist lizenziert unter einer Creative Commons Namensnennung 4.0 International Lizenz.

This is an open access article licensed under a

Creative Commons Attribution 4.0 International License.

veröffentlicht / first published: 01/04/2005

zuletzt geändert / last updated: 15/01/2010 


\section{Popular Music Analysis in American Music Theory}

Jocelyn Neal

\section{Introduction}

At the 1998 annual conference of the Society for Music Theory, individuals whose research included the analysis of popular music organized an "interest group," chaired by John Covach. While this Popular Music Interest Group created an important interactive network for scholars with common interests, it was merely one manifestation of a growing sub-discipline within music theory. The "analysis of popular music" brought formal analytic techniques to bear on new repertory, but at the same time opened up compelling avenues for interdisciplinary research to music theorists.

Any discussion of popular music analysis within the field of music theory must consider the definitions of both "popular music" and "analysis." Scholars from a wide range of disciplines have studied and analyzed popular music for several decades; however, the core music theory community, loosely represented by the Society for Music Theory's members and their generally adopted analytic approaches, has only been openly engaged in these pursuits for the past fifteen years or so. Thus, how narrowly one defines "analysis" determines how far one can look, both afield and back in time, to find relevant writing.

Similarly, the definitions of "popular music" invoked when discussing music-theoretic disciplines are ambiguous at best. In these contexts, discussants seldom make fine distinctions between folk, popular, and art music, for instance, as are found in scholarly literature. Instead, the idea of "analyzing popular music" carried implications in its early incarnations of a formalist approach to rock music, and even more specifically, the rock music of the 1960s, 1970s, and possibly early 1980s that was canonized within rock histories. In recent years, that focus has expanded to the point that the "analysis of popular music" now engages genres as disparate as rock music, country music, electronic dance music, pop, hip hop, and soul, just to name a few.

\section{Histories within the Discipline}

Because popular music analysis by its nature spans multiple methodologies, repertoires, and disciplines, its history within music theory must be examined in part through a history of people and events. One significant point of emergence for popular music analysis was a conference session devoted to the subject at the 1990 joint meeting of the Society 
for Music Theory (SMT) and the American Musicological Society (AMS), held in Oakland, California. The five session participants laid claim to the first analytic conference session on popular music analysis at either society's national meetings. ${ }^{1}$ Although there existed plenty of literature on the addressed that day, what distinguished their work was their employment of structural and formalist analytic approaches, and an overt attention to "the music itself" as subject.

It is unsurprising that a generation of theorists who grew up with both classical and rock music experiences instinctively applied their expertise to both repertories. ${ }^{2}$ Such breadth of interests led to a 1996 conference hosted at the Eastman School of Music, titled Cross(Over) Relations, and advertised as an opportunity for theorists to present research on music that had previously not been accepted as viable subject matter by the discipline at large. ${ }^{3}$

Two edited collections appeared during this era that helped establish popular music analysis as a respected area for scholarly publishing. While other contemporaneous texts also analyzed rock music, they had garnered less attention from the American music theory community. ${ }^{4}$ The first of the new arrivals, Elizabeth West Marvin and Richard Hermann's Concert Music, Rock, and Jazz Since 1945, caught reviewers' attention with the editors' claims that the book's diversity of contents "celebrates both the increasing pluralism of topics and approaches found in recent music scholarship, and the supposed collapse between 'high' and 'low' culture (and by extension, 'classical' and 'popular' music) noted by some theorists of postmodernism." ${ }^{\prime 5}$ The book's juxtaposition of articles on Led Zeppelin, Spinal Tap, and Abbey Road with articles on Stockhausen, Elliott Carter, and Berio's Sequenza IV was reminiscent of an approach Robert Gauldin used in "Beethoven, Tristan, and the Beatles," warmly regarded as one of the earliest popular music-analytic articles, where techniques of large-scale formal analysis and consideration of key relations were applied to side by side to canonic art repertory and popular music. ${ }^{6}$

The second edited collection to challenge the lack of popular analysis within the music theoretic literature was John Covach and Graeme Boone's Understanding Rock: Essays in Musical Analysis, conceived several years earlier from the papers presented at the 1990 Oakland conference session. ${ }^{7}$ In its seven constituent essays, analyses of harmony, voice-leading, form, motive, reference, narrative, and text / music relations led to interpretive conclusions about the music of the Beach Boys, Cream, Paul Simon, the Grateful Dead, and others.

1 Covach and Boone 1997, vii. Presenters on that conference session were Graeme Boone, Matthew Brown, John Covach, Walter Everett, and Dave Headlam. Robert Gauldin chaired the Friday evening session.

2 Kaminsky pointed this out (Kaminsky 2000), as have several participating theorists in biographical statements.

3 The Cross(Over) Relations conference was organized by Dave Headlam and Robert Fink.

4 See, for instance, Moore 1993. Walser 1993 also includes detailed analyses.

5 Brackett 1997, 95.

6 Gauldin 1990. The relevant articles from the collection are Headlam 1995, Covach 1995, and Everett 1995.

7 Covach and Boone 1997. The authors in the volume are John Covach, Daniel Harrison, Dave Headlam, Lori Burns, Walter Everett, Matthew Brown, and Graeme M. Boone. 
At the same time that these texts were appearing, general trends in higher education renewed interest in many music departments toward offering popular music courses. Job descriptions on occasion noted "popular music" as a preferred secondary area of specialization, which fueled interest in the sub-discipline, while undergraduate courses in rock music and related subjects brought large numbers of students into the classroom. Furthermore, music theory as a discipline was undergoing a process of self-examination that began to challenge the hegemony of core methodologies such as Schenkerian analysis and post-tonal analysis.

These processes allowed room, metaphorically speaking, for popular music analysis. Robert Fink made a compelling case for musicologists' and theorists' voices in the analysis of popular music by that the hierarchy of "classical" over "popular" music had indeed collapsed, rendering the study of popular musics essential. ${ }^{8}$ Fink's model for such study included formal analysis as one necessary component. This type of work has slowly but surely moved into wide-scale acceptance within the discipline: evidence is found in the recent publication of two popular music analyses in Music Theory Spectrum, as well as frequent sessions on popular music analysis at SMT and AMS. ${ }^{9}$

\section{Methodological Issues}

In defining their ideological domains, music theorists writing on popular music have frequently referenced Philip Tagg's early article, "Analysing Popular Music: Theory Method and Practice," which outlined an approach that included formal analysis as one component within a broadly interdisciplinary paradigm for analysis. ${ }^{10}$ In spite of the generally accepted call for interdisciplinary approaches, however, some authors working outside music theory challenged the usefulness of formal musical analysis in any role. Richard Middleton's Studying Popular Music included a chapter titled "'Change Gonna Come'? Popular Music and Musicology," which discounted the approach entirely and warned of the "musicological problem" of adopting established analytic methodologies to popular music. ${ }^{11}$ Susan McClary and Robert Walser contributed to the polemic debate over the role of formal analysis, arguing that music theorists "find themselves burdened with the hidden ideological claptrap of their ... training." ${ }^{\prime 2}$ Although they, too, call for an interdisciplinary approach to analyzing popular music, they dismiss overly formal music-

8 Fink 1998, esp. pp. 136, 138, and 164-165.

9 Capuzzo 2004 and Everett 2004a. Similar acceptances of the scholarship of popular music are in evidence in other scholarly disciplines; see, for instance, the Journal of the American Musicological Society's recent publication on Bob Dylan and Jimi Hendrix (Zak 2004). Many theorists have casually remarked on the appearance of popular music analysis in the flagship journals.

10 Tagg 1982, 45-46.

11 Middleton 1990, 103-105. Regarding Middleton's stance, Allen Forte comments, “Middleton's confusion... of analytical approaches and his evident need to satisfy the pressures of the new musicologists is documented, including yet one more derogatory reference by Middleton to 'formalist music theory,' a tiresome, but apparently obligatory gesture" (Forte 2000).

12 McClary and Walser 1988, 281. 
theoretic approaches as missing the point and obscuring listeners' understanding of the music's visceral power.

"Writers in popular-music scholarship sometimes set up the theorist... as a straw man, as a caricature that serves as a foil to their own ideas. It is as if these writers were against the idea of theorists examining popular music as a matter of principle," responded John Covach. ${ }^{13}$ Fundamental questions underscoring this debate include whether or not popular music is structurally "interesting," and therefore, worthy of formal analytical examination, and whether or not the resulting analyses are informative when considered within the music's social and cultural contexts. Detractors claim that the specialized notation employed in structural analysis, and even the use of conventional transcription, can obfuscate the subject matter. ${ }^{14}$ Furthermore, those authors argue, while the apparent objectivity of "formalist analytical methods" and "an inferiority complex" held by musicologists have tempted scholars toward these techniques, they produce flawed results. ${ }^{15}$ Theorists counter that analytic attempts which eschew more sophisticated music-theoretic systems are extremely limited in what they can accomplish, and thus, these arguments have not dissuaded theorists from their work. ${ }^{16}$

What has persisted in recent years is a profound interest from both music theorists and their readership in the close examination and analysis of the musical substance. Music theorists brought the established methodologies of close readings and formal analysis to bear on these repertories, but at the same time, began to move increasingly toward interdisciplinary approaches toward reasoning within those analyses. Schenkerian and voice-leading analyses formed the foundation for many of the early analyses of popular music, as did the study of harmony, form, and text / music relations. ${ }^{17}$ However, current music-analytic literature draws just as readily from source studies, examination of recording studio techniques, musical semiotics, timbral studies, neo-Riemannian techniques, and rhythmic and metric analytical theories. ${ }^{18}$ Studies of hook, groove, rhythm, meter, and phrase structure in particular have emerged with frequency in recent years. ${ }^{19}$ As the larger discipline of music theory has embraced a wider array of sub-disciplines, music theorists working on popular music have similarly broadened their own definitions of "analysis," leading to work that is as at home in critical theory and cultural studies as in music theory. ${ }^{20}$ Cultural, semiotic, and narrative readings are merging with formal analyses. Perhaps as a result, some of the tensions from the polemic debates have dissipated. Ironically, these expansions and overlaps in methodologies have resurrected the question of what constitutes a specifically music-theoretic analysis of popular music.

13 Covach 1997a, 130-131; emphasis in the original text.

14 McClary 1990, 279.

15 Walser 2003, 18.

16 For consideration, Walser 2003 offers four analyses that skirt the use of music-theoretical models, with subsequently limited results.

17 See, for instance, Everett 1987, Everett 1992, Burns 1997, Ricci 2000, Spicer 2004.

18 Zak 2001 in particular focused on the recording studio and the processes of analyzing sound.

19 See, for instance, Butler 2001 and Neal 2000.

20 See, for instance, Krims 2000 and individual articles in Holm-Hudson 2000a. 


\section{What is "Popular Music"?}

Recent music-theoretic work has also broadened the understood definitions of the term "popular music." Early writings carried a strong bias toward rock, and specifically rock of the 1960s and 1970s, as its core repertory. Comments by some writers asserted that not all "popular" music would hold up to structural analysis; Kaminsky even suggested that a title such as "The Backstreet Boys as Musicians" would only function as parody of a respectable work, "The Beatles as Musicians."21 Certainly, structural analysis of selected rock and pop repertory has revealed complex harmonic languages and sophisticated pitch-based compositional techniques that engage the readership. ${ }^{22}$ But the outdated, tacit assumption that the analysis of popular music was loosely limited to rock music or music of notable harmonic sophistication has been eliminated in recent years as representations of other genres have taken root in the sub-discipline.

Analyses of popular song, specifically from the Tin Pan Alley tradition, appear within the conversation with some regularity. ${ }^{23}$ Recent dissertations on country music, electronic dance music, and pop, all drawing on rigorous, formal analytic techniques, illustrate the increasing breadth of the sub-discipline. ${ }^{24}$ Not all genres that fit under the most inclusive definitions of popular music have been brought to the table, however. Jazz, for instance, had previously established its own SMT interest group and academic space. Film music, likewise, has preserved its separate domain.

Just what constitutes analysis of popular music from a music-theoretic perspective remains difficult, if not impossible, to define. Insightful close readings of music have appeared in outlets not generally associated with music theory, while self-identified music theorists readily adopt analytic approaches from cultural studies and other disciplines. What unifies this sub-discipline of popular music analysis is a deep and rigorous attention to the specifically musical elements of its subject matter. The over-used assertion that popular music analyses address "the music itself" remains accurate, although in current practice, the methodological contexts in which that research takes place are richly informed by neighboring disciplines. Neither methodological approach nor repertory is constrained, leaving perhaps only the scholar's ideological persuasion as definitive.

\section{Selected Bibliography and Reference List}

Berry, David Carson. 2001. "Gambling with Chromaticism? Extra-Diatonic Melodic Expression in the Songs of Irving Berlin." Theory and Practice 26: 21-85.

Boone, Graeme M. 1997. "Tonal and Expressive Ambiguity in 'Dark Star'." In Understanding Rock: Essays in Musical Analysis, edited by John Covach and Graeme M. Boone. New York: Oxford University Press, 171-210.

21 Kaminsky 2000, commenting favorably on Everett 1999.

22 Everett 2004a is a prime example.

23 See, for instance, Forte 1995 and Berry 2001.

24 See Neal 2002, Butler 2003, and Hughes 2003. 
Bowman, Rob. 1995. "The Stax Sound: A Musicological Analysis." Popular Music 14: 285-320.

Brackett, David. 1995. Interpreting Popular Music. Cambridge: Cambridge University Press. - 1997. Review of Concert Music, Rock, and Jazz Since 1945: Essays and Analytical Studies, edited by Elizabeth West Marvin and Richard Hermann. American Music 15: 95-99.

Brown, Matthew. 1997. "'Little Wing': A Study in Musical Cognition." In Understanding Rock: Essays in Musical Analysis, edited by John Covach and Graeme M. Boone. New York: Oxford University Press, 155-196.

Burns, Lori. 1997. "Joanie' Get Angry: k.d. lang's Feminist Revision." In Understanding Rock: Essays in Musical Analysis, edited by John Covach and Graeme M. Boone. New York: Oxford University Press, 93-112.

— and Alyssa Woods. 2004. "Authenticity, Appropriation, Signification: Tori Amos on Gender, Race, and Violence in Covers of Billie Holiday and Eminem." Music Theory Online 10. http://societymusictheory.org/mto/issues/mto.04.10.2/mto.04.10.2.burns_ woods_frames.html.

Butler, Mark J. 2001. "Turning the Beat Around: Reinterpretation, Metrical Dissonance, and Asymmetry in Electronic Dance Music." Music Theory Online 7. http://societymusictheory.org/mto/issues/mto.01.7.6/mto.01.7.6.butler_frames.html.

- 2003. "Unlocking the Groove: Rhythm, Meter, and Musical Design in Electronic Dance Music." Ph.D. Diss., Indiana University.

Capuzzo, Guy. 2004. "Neo-Riemannian Theory and the Analysis of Pop-Rock Music." Music Theory Spectrum 26: 177-199.

Covach, John. 1995. "Stylistic Competencies, Musical Satire, and 'This Is Spinal Tap'." In Concert Music, Rock, and Jazz Since 1945: Essays and Analytical Studies, edited by Elizabeth West Marvin and Richard Hermann. Rochester, NY: University of Rochester Press, 399-421.

— 1997a. "Analysis: What Is It Good For? We Won't Get Fooled Again - Rock Music and Musical Analysis." In Theory Only 13: 117-142.

- 1997b. "Close to the Edge,' and the Boundaries of Style." In Understanding Rock: Essays in Musical Analysis, edited by John Covach and Graeme M. Boone. New York: Oxford University Press, 3-31.

_ and Graeme M. Boone, eds. 1997. Understanding Rock: Essays in Musical Analysis. New York: Oxford University Press.

Everett, Walter. 1986. "Fantastic Remembrance in John Lennon's Strawberry Fields Forever and Julia." Musical Quarterly 72: 360-393.

- 1987. "Text-Painting in the Foreground and Middleground of Paul McCartney's Beatle Song, 'She's Leaving Home': A Musical Study of Psychological Conflict," In Theory Only 9: 5-21.

- 1992. "Voice Leading and Harmony as Expressive Devices in Early Music of the Beatles: 'She Loves You'." College Music Symposium 32: 19-37. 
1995. "Beatles as Composers: The Genesis of Abbey Road, Side Two." In Concert Music, Rock, and Jazz Since 1945: Essays and Analytical Studies, edited by Elizabeth West Marvin and Richard Hermann. Rochester, NY: University of Rochester Press, 172-228.

—. 1997. "Swallowed by a Song: Paul Simon's Crisis of Chromaticism." In Understanding Rock: Essays in Musical Analysis, edited by John Covach and Graeme M. Boone. New York: Oxford University Press, 113-153.

— 1999. The Beatles as Musicians: "Revolver" through the "Anthology." Oxford: Oxford University Press.

—. Ed. 2000. Expressions in Pop-Rock Music. New York: Garland Publishing, Inc.

—. 2004a. "A Royal Scam: The Abstruse and Ironic Pop-Rock Harmony of Steely Dan." Music Theory Spectrum 26: 201-235.

—. 2004b. "Making Sense of Rock's Tonal Systems." Music Theory Online 10. http:// societymusictheory.org/mto/issues/mto.04.10.4/mto.04.10.4.w_everett_frames.html.

Fink, Robert. 1998. "Elvis Everywhere: Musicology and Popular Music Studies at the Twilight of the Canon." American Music 16: 135-179.

Forte, Allen. 1995. The American Popular Ballad of the Golden Era, 1924-1950. Princeton: Princeton University Press.

—. 2000. "Responses to Plenary Session Papers, NECMT 2000 (With Replies from Some Presenters)." Music Theory Online 6. http://societymusictheory.org/mto/issues/ mto.00.6.3/mto.00.6.3.forte_frames.html.

Gauldin, Robert. 1990. "Beethoven, Tristan, and the Beatles." College Music Symposium 30: 142-152.

Harrison, Daniel. 1997. "After Sundown: The Beach Boys' Experimental Music." In Understanding Rock: Essays in Musical Analysis, edited by John Covach and Graeme M. Boone. New York: Oxford University Press, 33-57.

Headlam, Dave. 1995. "Does the Song Remain the Same?: Questions of Authorship and Identification in the Music of Led Zeppelin." In Concert Music, Rock, and Jazz Since 1945: Essays and Analytical Studies, edited by Elizabeth West Marvin and Richard Hermann. Rochester, NY: University of Rochester Press, 313-363.

—. 1997. "Blues Transformations in the Music of Cream." In Understanding Rock: Essays in Musical Analysis, edited by John Covach and Graeme M. Boone. New York: Oxford University Press, 59-92.

Holm-Hudson, Kevin, ed. 2002a. Progressive Rock Reconsidered. New York: Routledge.

- 2002b. "Your Guitar, It Sounds So Sweet and Clear: Semiosis in Two Versions of 'Superstar'." Music Theory Online 8. http://societymusictheory.org/mto/issues/ mto.02.8.4/mto.02.8.4.holm-hudson_frames.html.

Hughes, Timothy S. 2003. "Groove and Flow: Six Analytical Essays on the Music of Stevie Wonder." Ph.D. Diss., University of Washington.

Kaminsky, Peter. 1992. "The Pop Album as Song Cycle: Paul Simon's Still Crazy After All These Years." College Music Symposium 32: 38-54. 
— 2000. "Revenge of the Boomers: Notes on the Analysis of Rock Music." Music Theory Online 6. http://societymusictheory.org/mto/issues/mto.00.6.3/mto.00.6.3.kaminsky_ frames.html.

Krims, Adam. 2000. Rap Music and the Poetics of Identity. Cambridge: Cambridge University Press.

Marvin, Elizabeth West and Richard Hermann, eds. 1995. Concert Music, Rock, and Jazz Since 1945: Essays and Analytical Studies. Rochester, NY: University of Rochester Press.

McClary, Susan and Robert Walser. 1988. "Start Making Sense! Musicology Wrestles with Rock." In On Record: Rock, Pop, and the Written Word, edited by Simon Frith and Andrew Goodwin. New York: Pantheon Books, 1990.

Middleton, Richard. 1990. Studying Popular Music. Milton Keynes: Open University Press.

_. 1993. "Popular Music Analysis and Musicology: Bridging the Gap." Popular Music 12: 177-190.

Moore, Allan F. 1992. "Patterns of Harmony." Popular Music 11: 73-106.

- 1993. Rock, the Primary Text: Developing a Musicology of Rock. Buckingham, England, and Philadelphia: Open University Press.

—. 1995. "The So-Called 'Flattened Seventh' in Rock." Popular Music 14: 185-201.

Neal, Jocelyn R. 2000. "Songwriter's Signature, Artist's Imprint: The Metric Structure of a Country Song." Country Music Annual 1: 112-140.

—. 2002. "Song Structure Determinants: Poetic Narrative, Phrase Structure, and Hypermeter in the Music of Jimmie Rodgers." Ph.D. Diss., Eastman School of Music, University of Rochester.

Ricci, Adam. 2000. "A Hard Habit to Break: The Integration of Harmonic Cycles and VoiceLeading Structure in Two Songs by Chicago." Indiana Theory Review 21: 129-146.

Spicer, Mark S. 2001. "British Pop-Rock Music in the Post-Beatles Era: Three Analytical Studies." Ph.D. Diss., Yale University.

- 2004. "(Ac)cumulativeForm in Pop-RockMusic." Twentieth-Century Music 1:29-64.

Tagg, Philip. 1982. "Analysing Popular Music: Theory, Method and Practice." Popular Music 2: 37-67.

Walser, Robert. 1993. Running with the Devil: Power, Gender, and Madness in Heavy Metal Music. Hannover, NH: University Press of New England.

—. 2003. "Popular Music Analysis: Ten Apothegms and Four Instances." In Analyzing Popular Music, ed. Allan F. Moore. Cambridge: Cambridge University Press.

Zak, Albin. 2001. The Poetics of Rock: Cutting Tracks, Making Records. Berkeley: University of California Press.

—. 2004. "Bob Dylan and Jimi Hendrix: Juxtaposition and Transformation - All Along the Watchtower." Journal of the American Musicological Society 57: 599-644. 